\title{
Direct seeding of dry forest tree species in abandoned pastures: effects of grass canopy and seed burial on germination
}

Received: 27 February 2013/ Accepted: 5 March 2014/Published online: 26 April 2014

(C) The Ecological Society of Japan 2014

\begin{abstract}
Natural tree regeneration in abandoned pastures can be hampered by various biotic and abiotic filters, including seed removal and predation. We tested the effects of maintenance and removal of grass and seed deposition (buried and unburied) on seed germination of 12 tree species in dry forest pastures. We obtained evidence supporting the hypothesis that seeds attain higher germination under a grass canopy than on bare ground. For most species, grass cover provides safety from seed predators and facilitates germination by providing a suitable microclimate with soil humidity similar to the forest. The hypothesis that buried seeds attain higher germination was not supported by our data. Predation and removal of unburied seeds ranged from 0 to $77 \%$ and, alone or together, were the major causes of nongermination. Direct seeding is a promising technique for revegetation of recently abandoned pastures in areas originally covered by tropical dry forests. The high germination rate of seeds deposited on the ground and under grass reduces costs during initial restoration stages, potentially facilitating the spread and use of this technique.
\end{abstract}

Keywords Direct sowing - Restoration · Facilitation · Seed predation $\cdot$ Germination

Electronic supplementary material The online version of this article (doi:10.1007/s11284-014-1143-4) contains supplementary material, which is available to authorized users.

E. de Souza Gomes Guarino $(\square)$

Embrapa Acre, Rodovia BR 364, km 14, Caixa Postal 321, Rio Branco, Acre CEP 69908-970, Brazil

E-mail: ernestino.guarino@embrapa.br

Tel.: + 55-68-32123235

A. Scariot

Embrapa Recursos Genéticos e Biotecnologia, Parque Estação Biológica, Av. W5 Norte (final), Caixa Postal 02372, Brasília, Distrito Federal, Brazil

\section{Introduction}

Declining productivity and economic changes are the most common reasons for the abandonment of agricultural lands. This situation is frequently observed in tropical areas, leading to drastic changes in ecosystem structure and function that require forest restoration for the rescue of biodiversity (Cusack and Montagnini 2004). Restoration of abandoned pastures in secondary forests is an important factor contributing to biodiversity conservation in forest ecosystems, but regeneration in these areas is slower than in disturbed forests (Uhl et al. 1988; Aide et al. 1995). Pasture regeneration is affected by several biotic and abiotic factors: (1) lack of vegetative propagules, (2) high predation of seeds and seedlings, (3) competition with exotic grasses, (4) periods of drought and (5) high soil degradation (Aide et al. 1995; Nepstad et al. 1996; Holl 1999; Holl et al. 2000). The relative importance of each factor varies greatly among species and among studied areas (Holl 1999).

Limited seed dispersal and seed predation are the first ecological filters that can prevent tree species from colonizing abandoned pastures (Nepstad et al. 1996; Holl et al. 2000). The large floristic composition difference between pasture and native forest, as well as distance to the nearest forest edge, may limit seed rain in pastures (Cubiña and Aide 2001). The number of seeds gradually declines with increasing distance from the forest edge, with seed rain in pastures 10 times lower on average than in mature forests (Holl 1999; Zimmerman et al. 2000; Cubiña and Aide 2001). Even if seeds succeed in dispersing into pastures, they are exposed to different survival challenges. Predation by insects or rodents is the first of several important selective filters for tree regeneration in tropical forests (Schupp 1988; Peña-Claros and De Boo 2002) and abandoned pastures (Aide and Cavelier 1994; Holl and Lulow 1997; Holl 1999; Jones et al. 2003). The outcome of seed predation can affect the recovery pattern of abandoned pastures (Holl and Lulow 1997; Holl et al. 2000). 
Avoiding direct contact between seeds and potential predators increases seedling establishment in pastures (Holl and Lulow 1997; Doust 2011). A simple technique to avoid such contact is to bury the seeds in the soil. The few studies that have tested this technique to restore tropical forests have found that seed burial increases seed germination (e.g., Camargo et al. 2002; GarciaOrth and Martínez-Ramos 2007; Doust 2011).

In abandoned pastures, grasses and herbs may improve micro-climatic conditions (light and temperature), creating favorable environmental conditions for the establishment and growth of secondary and climax tree species. This positive interaction is defined as a plant facilitation relationship (Callaway 1995, 2007; Brooker et al. 2008). Because of the high costs associated with terrestrial ecosystem restoration, the ecological mechanisms behind plant facilitation are increasingly being discussed (Brooker et al. 2008). Examples involving facilitation or inhibition of seed germination in abandoned pastures show distinct results, with grasses either facilitating (e.g., Holl 1999; Zimmerman et al. 2000) or inhibiting (e.g., Aide and Cavelier 1994) germination. This relationship depends on the seasonality of the environment, with plant cover being more important for seed germination in more seasonal environments than in moister environments (Vieira and Scariot 2006a). In pastures formerly occupied by dry forests, grasses are expected to play a facilitating role in tree seed germination.

The most widespread method for the recovery of degraded areas is planting nursery-raised tree seedlings: an expensive, laborious and generally time-consuming technique (Cole et al. 2011). An alternative, rarely used strategy is direct seeding, which is recommended for restoring areas that are large, difficult to access and with high seedling production costs (Sampaio et al. 2007a; Bonilla-Moheno and Holl 2010; Cole et al. 2011). The main disadvantages of this strategy are dependency on soil conditions, competition from weeds and grasses, low seed survival and germination, slow seedling growth compared with that of seedlings from nurseries and increased susceptibility to climate conditions (Parrotta and Knowles 1999; Engel and Parrotta 2001; Camargo et al. 2002). Despite these disadvantages, some studies have indicated that direct seed sowing is an attractive alternative because of its low cost, especially when the goal is to restore large areas (Engel and Parrotta 2001). Still, studies are needed to quantify the costs associated with this method and to identify species in which it is effective.

The aim of this study was to evaluate the potential of direct seeding of a range of tree species as a technique for restoring recently abandoned pastures in areas previously covered by dry forests. To this end, we experimentally evaluated the effects of maintenance and removal of pasture grasses and seed deposition (buried or on the ground) on the germination of 12 tree species. We tested the hypotheses that (1) seeds deposited under a grass canopy have higher germination rates than seeds deposited on bare ground, and (2) buried seeds have higher germination rates than unburied seeds.

Our results may help identify germination bottlenecks to dry forest restoration of abandoned pastures for a large proportion of species in the regional tree community. The 12 evaluated species represent at least $25 \%$ of the 44-48 tree species found in the study region's dry forests, with 8 of these species among the most important tree community components (Scariot and Sevilha 2005). For this reason, knowledge concerning how to restore populations of these species can contribute to the reestablishment of most dry forest species.

\section{Methods}

\section{Study area}

The study was conducted in three newly abandoned pastures located in the municipality of São Domingos in the northeastern corner of Goiás state, Brazil. This region is situated in the Paranã River Basin $\left(59,404 \mathrm{~km}^{2}\right)$, where the main vegetation types are cerrado (savanna) woodland, woodland, gallery forest, grasslands and deciduous and semideciduous forests. The seasonal deciduous forests are most abundant in elevations between 400 and $600 \mathrm{~m}$ a.s.l. in the terrain depression known as Vão do Paranã, a geosystem characterized by flat topography and dominated by nitisols (IUSS Working Group WRB 2006) derived from limestone (IBGE 1995). Nitisols, which occur in the three studied areas, are deep, well-drained, red, fertile soils with more than $30 \%$ clay. All studied sites share the same soil properties. The climate is Aw of Köppen (dry winters), with a distinct dry season from May to October; the mean annual temperature is $23.3^{\circ} \mathrm{C}$ (IBGE 1995), and the mean annual rainfall between 1969 and 2002 was $1.219 \mathrm{~mm}$ (http://www.ana.gov.br).

Grazing in the three pastures-Mocambo (MOC: $13^{\circ} 46^{\prime} 18^{\prime \prime} \mathrm{S}, 46^{\circ} 37^{\prime} 03^{\prime \prime} \mathrm{W}, \sim 13 \mathrm{ha}$ ), Monte Alto 1 (MA1: $\left.13^{\circ} 46^{\prime} 45^{\prime \prime} \mathrm{S}, 46^{\circ} 37^{\prime} 05^{\prime \prime} \mathrm{W}, \sim 14 \mathrm{ha}\right)$, and Monte Alto 2 (MA2: $13^{\circ} 46^{\prime} 18^{\prime \prime} \mathrm{S}, \quad 46^{\circ} 37^{\prime} 03^{\prime \prime} \mathrm{W}, \sim 1.0$ ha) - ended approximately 12 months before the start of the experiments. To prevent cattle from entering, we fenced the pastures. Exotic grasses predominate in these pastures, with MOC and MA1 dominated by Andropogon gayanus Kunth (andropogon) and MA2 by Panicum maximum Jacq. (Tanzania grass). These two species and Brachiaria decumbens Stapf predominate in most pastures in the region.

\section{Study species}

We selected 12 native tree species based on their potential high economic and phytosociological importance, their utility as a food source for local wildlife and their seed availability during the study period. The selected 
species were amburana (Amburana cearensis (Allemão) A. C. Sm.), aroeira (Myracrodruon urundeuva Allemão), braúna (Schinopsis brasiliensis Engl.), cagaita (Eugenia dysenterica DC.), cedro (Cedrela fissilis Vell.), chichá (Sterculia striata A. St.-Hil. \& Naudin), imbiruçu (Pseudobombax longiflorum (Mart. \& Zucc.) A. Robyns), mutamba (Guazuma ulmifolia Lam.), pajeú (Triplaris gardneriana Wedd.), pau-ferro (Machaerium scleroxylon Tul.), peroba (Aspidosperma pyrifolium Mart.) and tamboril (Enterolobium contortisiliquum (Vell.) Morong). Except for Eugenia dysenterica, Enterolobium contortisiliquum and Sterculia striata, all of these species have wind-dispersed seeds (Table 1). Seed quality data for most species, obtained from the same seed pool used in this study, can be found in Lima et al. (2008).

\section{Experimental design and environmental variables}

We collected seeds from the study area during the months of July and August, except for Eugenia dysenterica, which was collected in October. Seeds were processed in the laboratory and stored in paper bags at room temperature. The seeds were not subjected to treatments to break dormancy. We removed the mesocarp of Eugenia dysenterica fruits under running water to enable temporary seed storage.

We laid out three $100-\mathrm{m}$ lines spaced $10 \mathrm{~m}$ apart in the MOC and MA1 pastures. Because of its smaller area, 90-m lines were set up in MA2. In each row, we designated 10 points at $10-\mathrm{m}$ intervals, which were used to define $4-\mathrm{m}^{2}(2 \times 2 \mathrm{~m})$ plots. In each plot, we established a combination of the effective levels of grass canopy (presence or absence) and seed deposition (buried or on the ground), and placed 12 seeds, one of each species, in four rows of three seeds, always in the same sequence. To avoid removal by wind and/or rain while allowing direct contact between seeds and soil, seeds on the ground were surrounded with a nylon mesh rim $(7 \mathrm{~cm}$ high $\times 10 \mathrm{~cm}$ diameter) fixed to the ground with wire staples. The nylon mesh rim was open at the top to allow seed predators and dispersers free access to seeds.
We set up the experiment in early December during the rainy season and monitored seed fate for 3 months. Seeds were monitored 3 days after sowing and weekly thereafter until the end of the second month (60 days), and then biweekly. Germination, defined as the emission of radicles or shoots, was recorded in each census. Nongerminated seeds were recorded as predated, removed or intact. To maintain the homogeneity of the plots subjected to grass removal, all vegetation regrowth was removed every 15 days by machete and sickle.

Using a convex spherical densiometer, we estimated the grass canopy at $0.5 \mathrm{~m}$ above ground in the centre of each plot. Four readings, one in each cardinal direction (North, South, East and West), were recorded and averaged. A total of 60 readings were taken in the three pastures [10 readings $\times 2$ levels of grasses (presence or absence) $\times 3$ pastures].

Soil moisture was estimated as the percentage of water in dry weight of soil by the gravimetric method. Soil samples were collected, weighed, and dried at $102{ }^{\circ} \mathrm{C}\left( \pm 2{ }^{\circ} \mathrm{C}\right)$ for $24-48 \mathrm{~h}$, with re-weighing performed until a constant weight was reached. A total of 90 samples were collected at the establishment of the experiment and again 2 months later [15 samples $\times 2$ levels of grass (presence or absence) $\times 3$ pastures $\times 2$ samplings]. We also measured the heights of 60 grass clumps in the studied pastures.

\section{Data analysis}

Statistical analyses were conducted in SAS V8.01 (SAS 1999) using a $p<0.05$ significance level. Grass clump heights were analyzed by ANOVA and Tukey's HSD test for multiple comparisons (Zar 1999). Because grass canopy and soil moisture data had non-normal distributions $(p>0.05$, Shapiro-Wilk), they were analyzed using nonparametric Mann-Whitney $(U)$ and KruskalWallis $(H)$ tests.

We evaluated only the values of germinated and nongerminated seeds. Seeds placed on the soil that were intact, predated or removed at the end of the study were considered to be non-germinated. Buried seeds that did

Table 1 Species list, average weight of seeds $(n=30, \pm 1 \mathrm{SD})$, seed dispersal and importance (fauna: $\mathrm{f}$ and timber: $\mathrm{t}$ ) of trees in this study

\begin{tabular}{|c|c|c|c|c|}
\hline Species & Family & Seed weight (g) & Dispersal & Importance \\
\hline Sterculia striata A. St.-Hil. \& Naudin & Sterculiaceae & $1.836 \pm 0.268$ & Zoochoric & $\mathrm{f}$ \\
\hline Enterolobium contortisiliquum (Vell.) Morong & Mimosaceae & $0.689 \pm 0.153$ & Zoochoric & $\mathrm{f}, \mathrm{t}$ \\
\hline Eugenia dysenterica DC. & Myrtaceae & $0.625 \pm 0.146$ & Zoochoric & $\mathrm{f}$ \\
\hline Amburana cearensis (Allemão) A. C. Sm. & Fabaceae & $0.452 \pm 0.083$ & Anemocoric & $\mathrm{f}, \mathrm{t}$ \\
\hline Aspidosperma pyrifolium Mart. & Apocynaceae & $0.352 \pm 0.079$ & Anemocoric & $\mathrm{t}$ \\
\hline Machaerium scleroxylon Tul. & Fabaceae & $0.196 \pm 0.060$ & Anemocoric & $\mathrm{t}$ \\
\hline Schinopsis brasiliensis Engl. & Anacardiaceae & $0.193 \pm 0.055$ & Anemocoric & $\mathrm{t}$ \\
\hline Myracrodruon urundeuva (Allemão) A. C. Sm. & Anacardiaceae & $0.179 \pm 0.002$ & Anemocoric & $\mathrm{t}$ \\
\hline Triplaris gardneriana Wedd. & Polygonaceae & $0.122 \pm 0.097$ & Anemocoric & $\mathrm{t}$ \\
\hline Pseudobombax longiflorum (Mart. \& Zucc.) A. Robyns & Bombacaceae & $0.053 \pm 0.013$ & Anemocoric & $\mathrm{t}$ \\
\hline Cedrela fissilis Vell. & Meliaceae & $0.031 \pm 0.009$ & Anemocoric & $\mathrm{t}$ \\
\hline Guazuma ulmifolia Pers. & Sterculiaceae & $0.007 \pm 0.002$ & Zoochoric & $\mathrm{f}, \mathrm{t}$ \\
\hline
\end{tabular}


not produce shoots, whether intact, predated or removed, were also classified as non-germinated.

We verified the partial correlation for each level of experimental stratification with the Cochran-MantelHaenszel $(\mathrm{CMH})$ test as implemented in SAS using PROC FREQ (SAS 1999). The main feature of this analysis is the stratification and control of the effects of factors that are part of the experimental design (Stokes et al. 1995). This procedure potentially removes the influence of confounding effects of explanatory variables that form the stratification, increasing the ability to detect associations through comparison of similar responses or similar objects (Stokes et al. 1995). To perform this test, we organized the data into contingency tables, with treatments in rows and the number of germinated and non-germinated seeds in each treatment in columns. We compared the frequency distribution of germinated and non-germinated seeds across treatment levels with the CMH test. This comparison was adjusted to the pastures by application of the Pearson $\chi^{2}$ test (SAS 1999).

After applying the $\mathrm{CMH}$ test, which was a preliminary analysis, we pooled the data (species with $p<0.05, \mathrm{CMH}$ ) and analyzed them using a generalized linear model (GLM). Because the response variable had a binomial distribution (germinated or non-germinated seeds), we used logistic regression with the logit link function, $\log (\mu)-\log (1-\mu)$, as implemented in PROC GENMOD (SAS 1994). We tested the parameters and contrasts estimated with the Pearson $\chi^{2}$ test (SAS 1994). We also calculated the odds ratio, the chance that a seed will germinate divided by the chance that the same seed will not germinate. Because the odds ratio presented was calculated from the model-generated estimates, the associated confidence interval $\left(\mathrm{CI}_{0.95}\right)$ was also computed.

\section{Results}

\section{Environmental variables}

Grass clump height means were significantly different among pastures $\left(\right.$ ANOVA $-\mathrm{F}_{(2,117)}=31.473$, $p \leq 0.0001$ ), being highest in MA2 (mean $\pm \mathrm{SD}$ : $2.91 \pm 0.27 \mathrm{~m})$, followed by MA1 $(2.66 \pm 0.26 \mathrm{~m})$ and then MOC $(2.53 \pm 0.32 \mathrm{~m})$. As expected, grass cover was significantly higher in areas with grasses than in areas where they had been removed (Table 2; MA1: $U$ test $=14.00, p=0.006 ; \quad$ MA2: $U$ test $=2.50$, $p \leq 0.001$; MOC: $U$ test $=7.50, p \leq 0.01$ ).

At the start of the experiment, a difference in soil moisture between plots with and without grass canopies was detected only in MA2 (MA1: $U$ test $=110.0$, $p=0.91 ;$ MA2: $U$ test $=53.0, \quad p=0.01 ;$ MOC: $U$ test $=87.0, p=0.29$ ). Two months later, all plots with grass canopies, regardless of pasture location, had higher soil moisture than plots without grass (MA1: $U$ test $=57.0, \quad p=0.02 ; \quad$ MA2: $U$ test $=40.0$, $p \leq 0.01$; MOC: $U$ test $=41.0, p \leq 0.01$ ). At the start of the experiment, soil moisture did not differ significantly among pastures (Kruskal-Wallis, $\mathrm{H}_{(2,90)}=2.13$, $p=0.344)$. Two months later, MA2 had a mean soil humidity higher than that of MOC and MA1 (KruskalWallis, $\left.\mathrm{H}_{(2,90)}=2.24, p \leq 0.0001\right)$.

\section{Germination}

Disregarding species identity, $24.7 \pm 15.3 \%$ of seeds germinated, with higher germination observed under grass canopies $(29.1 \pm 17.4 \%)$ than in areas without grasses $(20.4 \pm 12.1 \%)$.

Of the 12 species, only Eugenia dysenterica, Enterolobium contortisiliquum and G. ulmifolia had no partial association between pasture and treatments $(p>0.05$, $\mathrm{CMH})$. Because of their low germination rates, $8 \%$ $(n=28), 2.5 \%(n=9)$ and $1 \%(n=4)$, respectively, these species were not further analyzed. The data from the remaining species, with $p<0.0001(\mathrm{CMH})$, were pooled ( $n=87$ seeds/treatment). Based on seed responses to the tested factors, three groups of species could be established. One group consisted of three species that responded significantly to grass canopy, regardless of whether the seeds were buried or not (Fig. 1; Table 3). Odds ratios estimated by the model for Amburana cearensis, C. fissilis and Sterculia striata demonstrate that more seeds germinated under grass canopy cover than when the grasses were removed (Fig. 1; Table 4).

The second group comprised three species that responded significantly, with or without grass canopy, to the method of seed deposition (Fig. 2; Table 3). Odds ratios estimated by the model indicate that Machaerium

Table 2 Grass cover $(\%$; mean $\pm \mathrm{SD})$ following treatments in studied pastures

\begin{tabular}{llll}
\hline Treatments & \multicolumn{2}{l}{ Pastures } & MA2 \\
\cline { 2 - 4 } & MA1 & $31.720 \pm 7.160^{\mathrm{a}}$ & MOC \\
\hline No thinning & $41.522 \pm 19.660^{\mathrm{a}}$ & $11.726 \pm 5.574^{\mathrm{b}}$ & $39.910 \pm 9.276^{\mathrm{a}}$ \\
Thinning & $18.512 \pm 14.311^{\mathrm{b}}$ & $21.940 \pm 8.626^{\mathrm{b}}$
\end{tabular}

Different lowercase letters indicate significant differences between grass cover treatments $(p<0.05, U$ test)

MA1 Monte Alto 1, MA2 Monte Alto 2, MOC Mocambo 

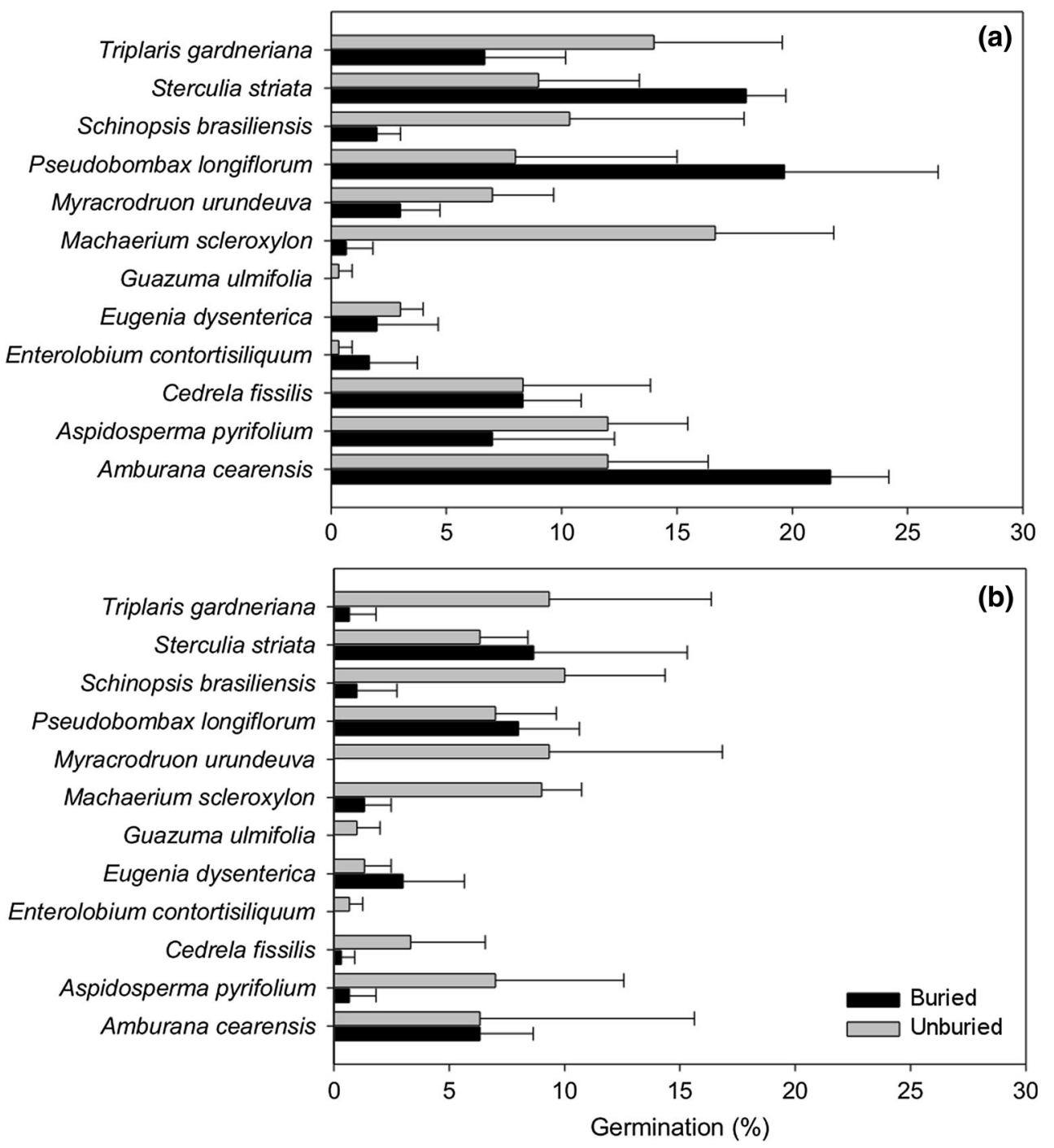

Fig. 1 Mean germination ( \pm SD) of 12 species after different grass canopy (a without grass canopy; b with grass canopy) and seed deposition (buried and unburied) treatments

scleroxylon, Myracrodruon urundeuva and Schinopsis brasiliensis had higher germination when seeds were placed on the ground than when they were buried (Fig. 1; Table 4). Schinopsis brasiliensis was the only species in this group whose germination was affected by pasture, which can be mainly attributed to its higher germination in MOC.

The third group was composed of species that responded to grass canopy presence and the placement of seeds on the ground, with no interaction between these factors (Fig. 1; Table 3). Estimated odds ratios indicate that 5.66 times more seeds of Aspidosperma pyrifolium germinated under grass canopy than when grasses were removed, and also when placed on the ground rather than buried (Table 4). Triplaris gardneriana had 5.26 times more seeds germinating under grass canopy than when grasses were removed, and 8.58 times more seeds germinating when placed on the ground rather than buried (Table 4). For Pseudobombax longiflorum, 2.67 times more seeds germinated under grass canopy than when grasses were removed, and 0.37 times more seeds germinated when they were buried than when placed on the ground. All estimates generated by the model were significant $(p<0.05)$. Even in the absence of significant interaction between treatments, seeds of Aspidosperma pyrifolium $(41 \%)$ and $T$. gardneriana $(48.3 \%)$ had the highest germination when they were placed on the ground under grass canopy; in contrast, $P$. longiflorum showed higher germination when seeds were buried without grass canopy $(67.8 \%)$.

Overall germination was weakly associated with seed mass $(r=0.24 ; p>0.05)$. Germination of unburied seeds under grass clumps, on the other hand, was significantly associated with seed mass $(r=0.60$; $p<0.05$; Fig. 2).

Seed predation and removal were the main causes of germination failure in seeds placed on the ground. In Amburana cearensis, C. fissilis, Eugenia dysenterica, 
Table 3 Results of logistic regression analysis of studied species with germination $>10 \%$

\begin{tabular}{|c|c|c|c|c|}
\hline Species & Sources of variation & df & $\chi^{2}$ & $p$ \\
\hline \multirow[t]{4}{*}{ Sterculia striata } & Pasture & 2,6 & 0.19 & 0.907 \\
\hline & Grass cover & 1,6 & 3.98 & 0.046 \\
\hline & Seed burial effect & 1,6 & 3.51 & 0.061 \\
\hline & Grass cover $\times$ seed burial & 1,6 & 0.88 & 0.347 \\
\hline \multirow[t]{4}{*}{ Amburana cearensis } & Pasture & 2,6 & 3.11 & 0.211 \\
\hline & Grass cover & 1,6 & 10.68 & 0.001 \\
\hline & Seed burial effect & 1,6 & 1.90 & 0.168 \\
\hline & Grass cover $\times$ seed burial & 1,6 & 1.90 & 0.168 \\
\hline \multirow[t]{4}{*}{ Aspidosperma pyrifolium } & Pasture & 2,6 & 2.33 & 0.311 \\
\hline & Grass cover & 1,6 & 7.21 & 0.007 \\
\hline & Seed burial effect & 1,6 & 7.21 & 0.007 \\
\hline & Grass cover $\times$ seed burial & 1,6 & 1.66 & 0.197 \\
\hline \multirow{4}{*}{ Machaerium scleroxylon } & Pasture & 2,6 & 3.55 & 0.169 \\
\hline & Grass cover & 1,6 & 0.12 & 0.734 \\
\hline & Seed burial effect & 1,6 & 54.32 & $<0.0001$ \\
\hline & Grass cover $\times$ seed burial & 1,6 & 2.56 & 0.109 \\
\hline \multirow[t]{4}{*}{ Schinopsis brasiliensis } & Pasture & 2,6 & 28.77 & $<0.0001$ \\
\hline & Grass cover & 1,6 & 1.31 & 0.2517 \\
\hline & Seed burial effect & 1,6 & 72.64 & $<0.0001$ \\
\hline & Grass cover $\times$ seed burial & 1,6 & 0.97 & 0.3257 \\
\hline \multirow{4}{*}{ Myracrodruon urundeuva } & Pasture & 2,6 & 5.28 & 0.053 \\
\hline & Grass cover & 1,6 & 0.39 & 0.512 \\
\hline & Seed burial effect & 1,6 & 5.03 & 0.018 \\
\hline & Grass cover $\times$ seed burial & 1,6 & 0.03 & 0.847 \\
\hline \multirow[t]{4}{*}{ Triplaris gardneriana } & Pasture & 2,6 & 5.59 & 0.061 \\
\hline & Grass cover & 1,6 & 7.68 & 0.005 \\
\hline & Seed burial effect & 1,6 & 14.25 & 0.0002 \\
\hline & Grass cover $\times$ seed burial & 1,6 & 2.08 & 0.149 \\
\hline \multirow{4}{*}{ Pseudobombax longiflorum } & Pasture & 2,6 & 3.93 & 0.140 \\
\hline & Grass cover & 1,6 & 5.31 & 0.021 \\
\hline & Seed burial effect & 1,6 & 5.31 & 0.021 \\
\hline & Grass cover $\times$ seed burial & 1,6 & 3.44 & 0.063 \\
\hline \multirow[t]{4}{*}{ Cedrela fissilis } & Pasture & 2,6 & 3.21 & 0.201 \\
\hline & Grass cover & 1,6 & 14.03 & 0.0002 \\
\hline & Seed burial effect & 1,6 & 2.63 & 0.104 \\
\hline & Grass cover $\times$ seed burial & 1,6 & 2.63 & 0.104 \\
\hline
\end{tabular}

$d f$ numerator and denominator degrees of freedom

Table 4 Studied tree species categorized by germination group

\begin{tabular}{|c|c|c|c|c|c|}
\hline Species & Germination group & Odds ratio & $\mathrm{CI}_{0.95}$ & $\chi^{2}$ & $p$ \\
\hline Amburna cearensis & GC & 5.6 & $1.9-16.8$ & 9.58 & $\leq 0.01$ \\
\hline Cedrela fissilis & & 10.8 & $1.7-66.8$ & 6.56 & $\leq 0.01$ \\
\hline Sterculia striata & & 2.5 & $1.0-6.2$ & 3.88 & $<0.05$ \\
\hline Machaerium scleroxylon & $\mathrm{Gr}$ & 24.3 & $7.5-78.8$ & 47.7 & $\leq 0.001$ \\
\hline Myracrodruon urundeuva & & 3.2 & $1.1-9.1$ & 28.21 & $\leq 0.001$ \\
\hline Schnopsis brasiliensis & & 0.9 & $0.6-1.2$ & 6.04 & $<0.05$ \\
\hline Aspidosperma pyrifolium & $\mathrm{GC}+\mathrm{Gr}$ & $5.66 / 5.66$ & $1.69-27.41 / 1.69-27.41$ & $22.81 / 31.16$ & $\leq 0.001$ \\
\hline Triplaris gardneriana & & $5.26 / 8.58$ & $1.22-22.49 / 2.00-36.81$ & $31.94 / 34.54$ & $\leq 0.001$ \\
\hline Pseudobombax longiflorum & & $2.67 / 0.37$ & $1.14-6.25 / 0.16-0.87$ & $23.53 / 32.49$ & $\leq 0.001$ \\
\hline
\end{tabular}

$C I$ confidence interval, $G C$ seeds placed under grass canopy, $G r$ seeds placed on the ground, $G C+G r$ seeds that responded to grass canopy and seed placement on the ground without interaction between these factors

Myracrodruon urundeuva and $P$. longiflorum, $\geq 50 \%$ of seeds were predated and removed (Table 5). Pathogens were important mortality agents in Aspidosperma pyrifolium and Sterculia striata seeds. Guazuma ulmifolia and Enterolobium contortisiliquum had the highest proportions of intact seeds, with $88.5-97.7 \%$ of seeds alive at the end of the study (Table 5).

\section{Discussion}

In most species with conclusive results, we obtained strong evidence for our hypothesis that grass canopy cover facilitates seed germination. Conversely, we found that the hypothesis that seed burial reduces seed 

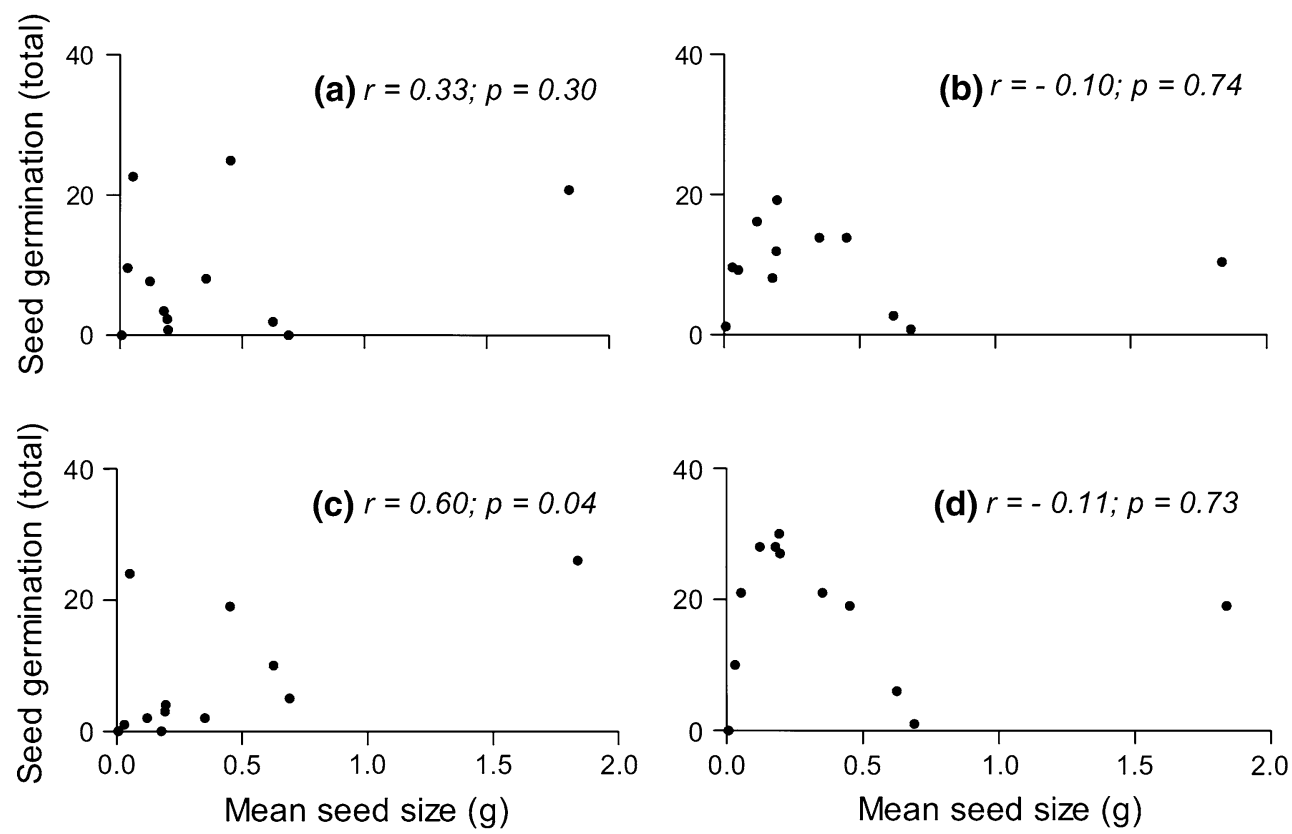

Fig. 2 Association between seed mass and total germination of 12 dry forest species in abandoned pastures in Central Brazil. Filled circle germinated seeds

predation and removal, thereby increasing germination in pastures, was not supported by our data. For most of the species tested, seed burial either decreased germination or had no effect. Restoration costs are reduced in pastures if high seed germination can be achieved by deposition of seeds on the ground and under grass canopy (Ray and Brown 1995; Negreros-Castillo et al. 2003). This strategy may thus be important for restoring pastures in deciduous dry forest ecosystems.

Seed dormancy, removal and predation impacts on germination

Our data support the idea that the time interval between seed arrival and germination is an important factor in restoration of native vegetation in pastures (Sampaio et al. 2007a; Bonilla-Moheno and Holl 2010). Average germination in our study, regardless of treatment, ranged from $1 \%$ (G. ulmifolia) to $40 \%$ (Amburana cearensis).

Seeds with dormancy, such as Enterolobium contortisiliquum and G. ulmifolia, may require interventions before sowing to improve germination: these species have poor germination when seeds are buried, with only 9.3 and $0.7 \%$ of seedlings emerging after 14 months, respectively (Sampaio et al. 2007a). The lower germination of Eugenia dysenterica is caused by high rates of seed predation and removal ( $\sim 75 \%$ in this study), a finding similar to that of Vieira and Scariot (2006b) in the same region. One way to reduce seed predation in the field is to accelerate their germination. This can be achieved by breaking seed dormancy and soaking seeds in water before sowing, thereby decreasing the length of exposure to seed predators (Camargo et al. 2002). In addition, seeds can be hidden from potential predators by placement within clumps of grasses and herbs or burial in the ground.

Do grass canopy and seed burial facilitate seed germination?

The grass canopy, even when not significant in the model, had facilitative effects on germination success of the remaining species (i.e., those with germination $>10 \%$; Fig. 2). By decreasing soil and air temperatures (Nepstad et al. 1996; Holl 1999; Zimmerman et al. 2000) and reducing water evaporation from the soil (Aide and Cavelier 1994), the grass canopy provides seeds with a micro-climate similar to that found in primary forests (Holl 1999; Zimmerman et al. 2000) and enhances seed germination. In our study area, soil moisture under the grass canopy was similar to soil moisture in dry deciduous forest fragments during the rainy season (pasture: $\sim 23 \%$; forests: 22 \%; see Guarino and Scariot 2012).

Grass canopy cover also reduces seed visibility to potential seed predators and provides a safe place for germination in pastures (e.g., Aide and Cavelier 1994; Holl et al. 2000; Zimmerman et al. 2000). Amburana cearensis, C. fissilis, S. striata, Aspidosperma pyrifolium, $P$. longiflorum and $T$. gardneriana seeds had higher germination under grass canopy and were less predated than when exposed due to grass removal (Table 5). Although a detailed study on the effects of grass competition in tree seedling establishment and growth in the studied area is required, our data show that grass cover promotes a safe and favorable site for germination. 
Table 5 Main causes of germination failure in unburied seeds

\begin{tabular}{|c|c|c|c|c|c|c|c|c|}
\hline \multirow[t]{3}{*}{ Species } & \multicolumn{8}{|c|}{ Germination failure $(\%)$} \\
\hline & \multicolumn{2}{|c|}{ Predation + removal } & \multicolumn{2}{|l|}{ Pathogens } & \multicolumn{2}{|l|}{ Desiccation } & \multicolumn{2}{|l|}{ Intact } \\
\hline & $\mathrm{GC}+\mathrm{UB}$ & $\mathrm{WGC}+\mathrm{UB}$ & $\mathrm{GC}+\mathrm{UB}$ & $\mathrm{WGC}+\mathrm{UB}$ & $\mathrm{GC}+\mathrm{UB}$ & $\mathrm{WGC}+\mathrm{UB}$ & $\mathrm{GC}+\mathrm{UB}$ & $\mathrm{WGC}+\mathrm{UB}$ \\
\hline Sterculia striata & 43.7 & 44.8 & 19.5 & 17.2 & 0.0 & 0.0 & 5.7 & 16.1 \\
\hline Enterolobium contortisiliquum & 8.0 & 12.6 & 1.0 & 0.0 & 0.0 & 0.0 & 88.5 & 86.2 \\
\hline Eugenia dysenterica & 77.0 & 74.7 & 0.0 & 1.0 & 0.0 & 0.0 & 11.4 & 19.5 \\
\hline Amburana cearensis & 54.0 & 72.0 & 3.5 & 5.7 & 0.0 & 0.0 & 1.0 & 0.0 \\
\hline Aspidosperma pyrifolium & 25.3 & 31.0 & 29.8 & 43.6 & 0.0 & 0.0 & 3.5 & 0.0 \\
\hline Machaerium scleroxylon & 17.2 & 19.5 & 0.0 & 0.0 & 0.0 & 0.0 & 25.3 & 49.4 \\
\hline Schinopsis brasiliensis & 48.3 & 33.3 & 0.0 & 1.0 & 0.0 & 0.0 & 17.3 & 31.0 \\
\hline Myracrodruon urundeuva & 73.5 & 66.6 & 2.3 & 0.0 & 1.0 & 0.0 & 0.0 & 1.0 \\
\hline Triplaris gardneriana & 46.0 & 59.7 & 1.0 & 0.0 & 0.0 & 0.0 & 4.6 & 8.0 \\
\hline Pseudobombax longiflorum & 67.8 & 73.5 & 0.0 & 1.0 & 0.0 & 0.0 & 4.6 & 1.0 \\
\hline Cedrela fissilis & 71.2 & 86.2 & 0.0 & 0.0 & 0.0 & 0.0 & 0.0 & 2.3 \\
\hline Guazuma ulmifolia & 1.0 & 1.0 & 0.0 & 0.0 & 0.0 & 0.0 & 97.7 & 95.4 \\
\hline
\end{tabular}

$G C$ grass cover, $W G C$ without grass cover, $U B$ unburied seeds

Some studies suggest that clumps of grass and shrubs do not affect the establishment and growth of seedlings (Aide and Cavelier 1994; Zimmerman et al. 2000; Loik and Holl 2001), while others suggest that grass cover may facilitate seedling establishment and growth of some species (Ray and Brown 1995; Holl 2002).

In contrast to findings indicating that seed burial effectively increases seed germination in pastures (e.g., Camargo et al. 2002; Garcia-Orth and Martínez-Ramos 2007; Sovu et al. 2010), our data demonstrate that this result is highly species-specific. Among the nine species with conclusive results, only P. longiflorum had higher seed germination when seeds were buried. Five species (Schinopsis brasiliensis, Machaerium scleroxylon, Myracrodruon urundeuva, Aspidosperma pyrifolium and $T$. gardneriana) exhibited higher seed germination rates when left unburied, while seed burial had no effect on germination of the remaining three (Amburana cearensis, C. fissilis and Sterculia striata). Nevertheless, seed burial can provide protection from predators in species with high seed predation (Vieira and Scariot 2006b; GarciaOrth and Martínez-Ramos 2007).

\section{Seed traits and germination success}

Large seeds have higher germination rates than intermediate and small seeds (Doust et al. 2006; Shankar 2006; Tunjai and Elliot 2012; Pereira et al. 2013), which is a commonly recognized pattern in seed ecology that is linked to the lower rates of seed removal/predation of large seeds (Hughes and Westoby 1992; Doust 2011). Small seeds are easier to handle than large seeds, which are thus only consumed by large animals (Osunkoya et al. 1994; Doust 2011). Although a few studies have indicated that seed germination rates are not related to seed size, this association is relatively weak ( $\mathrm{Paz}$ et al. 1999; Wang et al. 2009). Contributing to this debate, our data show that overall seed germination was not associated with seed mass (a proxy for seed size). This was true only for unburied seeds under grass tussocks, however, reinforcing the idea that grass tussocks provide safety for unburied seeds. The lack of overall association in our study between seed size and germination success was most likely due to the small range of seed sizes used. With the exception of G. ulmifolia seeds $(<0.01 \mathrm{~g})$, all investigated seeds could be classified as intermediate in size (0.01-4.99 g; sensu Doust et al. 2006). In similar studies, seeds with this approximate mass have not been associated with higher germination success (Doust et al. 2006; Pereira et al. 2013).

Dry tropical forests of Central Brazil are dominated by wind-dispersed species (45\%; Figueiredo 2002), which can colonize large areas and occur more frequently in abandoned pastures than do animal-dispersed species (Holl 1999). As suggested by Wang et al. (2009, 2012), this distribution can be partially explained, without accounting for phylogenetic effects, by variations in germination rates across species constrained by seed dispersal modes. These authors have shown that germination rates are strongly influenced by dispersal mode, and that germination rates of wind-dispersed seeds are higher than of unassisted-dispersed and vertebrate-dispersed seeds. Yang et al. (2013) further have indicated that wind-dispersed seeds germinate faster than unassisted-dispersed and vertebrate-dispersed seeds. Aside from evolutionary constraints on germination, wind-dispersed species may find safe sites under grasses and shrubs in abandoned pastures, where they attain higher germination and establishment rates than animal-dispersed species (Holl 1999).

Implications for restoration of seasonal deciduous forests: an endangered ecosystem

Our results are important for defining restoration strategies for seasonal deciduous forests, which are among the most threatened tropical ecosystems (Janzen 1988; Vieira and Scariot 2006b). Because of unplanned 
human settlement, forest remnants of seasonal deciduous forests in the tropics have different levels of disturbance and are embedded in a matrix composed mainly of pastures planted with exotic grasses. Restoring the connections between these fragments is essential to preserve biological integrity, maintain ecosystem functions and conserve biodiversity.

The different germination rates of the studied trees suggest that rather than direct seeding of all species, varied strategies are needed for the restoration of pastures in deciduous forests. Direct seeding can be used for most of the studied species, with grass cover retained to provide safety and a suitable microclimate for increased seed germination. Populations of rare or sporadically fruiting zoochorous species, whose seeds are difficult to obtain, can be restored via seedling introduction or through vegetative means (Vieira and Scariot 2006b; Sampaio et al. 2007b).

Direct seeding should be performed soon after the onset of the rainy season. This timing minimizes the period of exposure to the sun and seed predators (Holl and Lulow 1997; Negreros-Castillo et al. 2003; GarciaOrth and Martínez-Ramos 2007), thereby reducing seed desiccation and increasing seedling survival (McLaren and McDonald 2003; Vieira and Scariot 2006a, b; Vieira et al. 2008). Knowledge of historical patterns of rainfall distribution increases the probability of success, as even short dry spells may increase mortality of seeds and newly germinated seedlings. Storage of seeds from a wide range of tree species under natural conditions (Lima et al. 2008; Vieira et al. 2008) can make the direct seeding strategy even more attractive.

Our results confirm that several species can be directly sown on the ground without the need to bury the seeds. Seed burial may only be necessary in species with high seed predation to evade seed predation and removal. For species with dormant seeds and hard seed coats (i.e., species belonging to the Fabaceae), it may be necessary to break dormancy (Cervantes et al. 1996). This latter factor requires further study.

Acknowledgments This research was funded by Embrapa Recursos Genéticos e Biotecnologia and Fundo Nacional de Meio Ambiente (FNMA). ESGG received a fellowship from the Conselho Nacional de Desenvolvimento Cientıfico e Tecnológico (CNPq) and Coordenação de Aperfeiçoamento de Pessoal de Nível Superior (CAPES). We are indebted to Daniel L. M. Vieira, Alexandre B. Sampaio, Anderson C. Sevilha, Mauricio B. Sampaio, Rodrigo L. L. Orihuela and Celia M. Torres for productive discussions and for help in analyzing and interpreting the results.

\section{References}

Aide TM, Cavelier J (1994) Barriers to lowland tropical forest restoration in the Serra Nevada de Santa Marta, Colombia. Restor Ecol 2:219-229

Aide TM, Zimmerman JK, Herrera L, Rosario M, Serrano M (1995) Forest recovery in abandoned tropical pastures in Puerto Rico. For Ecol Manag 77:77-86
Bonilla-Moheno M, Holl KD (2010) Direct seeding to restore tropical mature-forest species in areas of slash-and-burn agriculture. Restor Ecol 18:438-445

Brooker RW, Maestre FT, Callaway RM, Lortie CL, Cavieres LA, Kunstler G, Liancourt P, Tielbörger K, Travis JMJ, Anthelme F, Armas C, Coll L, Corcket E, Delzon S, Forey E, Kikvidze Z, Olofsson J, Pugnaire F, Quiroz CL, Saccone P, Schiffers K, Seifan M, Touzard B, Michalet R (2008) Facilitation in plant communities: the past, the present, and the future. J Ecol 96:18-34

Callaway RM (1995) Positive interactions among plants. Bot Rev 61:306-349

Callaway RM (2007) Positive interactions and interdependence in plant communities. Springer, Dordrecht

Camargo JLC, Ferraz IDK, Imakawa AM (2002) Rehabilitation of degraded areas of central Amazonia using direct sowing of forest tree seeds. Restor Ecol 10:636-644

Cervantes V, Carabias J, Vázques-Yanes C (1996) Seed germination of woody legumes from deciduous tropical forest of southern Mexico. For Ecol Manag 82:171-184

Cole RJ, Holl KD, Keene CL, Zahawi RA (2011) Direct seeding of late-successional trees to restore tropical montane forest. For Ecol Manag 261:1590-1597

Cubiña A, Aide TM (2001) The effect of distance from forest edge on seed rain and soil seed bank in a tropical pasture. Biotropica $33: 260-267$

Cusack D, Montagnini F (2004) The role of native species plantations in recovery of understory woody species in degraded pasture lands of Costa Rica. Forest Ecol Manag 188:1-15

Doust SJ (2011) Seed removal and predation as factors affecting seed availability of tree species in degraded habitats and restoration plantings in rainforest areas of Queensland, Australia. Restor Ecol 19:617-626

Doust SJ, Erskine PD, Lamb D (2006) Direct seeding to restore rainforest species: microsite effects on the early establishment and growth of rainforest tree seedlings on degraded land in the wet tropics of Australia. For Ecol Manag 234:333-343

Engel VL, Parrotta JA (2001) An evaluation of direct seeding for reforestation of degraded lands in central São Paulo state, Brazil. For Ecol Manag 152:169-181

Figueiredo IB (2002) Padrões de polinização e dispersão de sementes de espécies arbóreas de floresta estacional decidual, Brasil Central. Bachelor Monograph, Instituto de Biociências, UNESP, Rio Claro

Garcia-Orth X, Martínez-Ramos M (2007) Seed dynamics of early and late successional tree species in tropical abandoned pastures: seed burial as a way of evading predation. Restor Ecol $16: 435-443$

Guarino ESG, Scariot A (2012) Tree seedling survival and growth in logged and undisturbed seasonal deciduous forest fragments in central Brazil. J For Res 17:193-200

Holl KD (1999) Factors limiting tropical rain forest regeneration in abandoned pasture: seed rain, seed germination, microclimate, and soil. Biotropica 31:229-242

Holl KD (2002) Effect of shrubs on tree seedling establishment in an abandoned tropical pasture. J Ecol 90:179-187

Holl KD, Lulow ME (1997) Effects of species, habitat, and distance from edge on post-dispersal seed predation in a tropical rainforest. Biotropica 29:459-468

Holl KD, Loik ME, Lin EHV, Samuels IA (2000) Tropical montane forest restoration in Costa Rica: overcoming barriers to dispersal and establishment. Restor Ecol 8:339-349

Hughes L, Westoby M (1992) Effect of diaspore characteristics on removal of seeds adapted for dispersal by ants. Ecology 73:1300-1312

IBGE - Instituto Brasileiro de Geografia e Estatística (1995) Zoneamento geoambiental e agroecológico do estado de Goiás: região nordeste. IBGE/Divisão de Geociências do Centro-Oeste, Rio de Janeiro

IUSS Working Group WRB (2006) World reference base for soil resources 2006. World soil resources reports no. 103. FAO, Rome 
Janzen DH (1988) Tropical dry forests, the most endangered major tropical ecosystem. In: Wilson EO (ed) Biodiversity. National Academy Press, Washington, pp 130-137

Jones FA, Peterson CJ, Haines BL (2003) Seed predation in neotropical pre-montane pastures: site, distance, and species effects. Biotropica 35:219-225

Lima VVF, Vieira DLM, Sevilha AC, Salomão AN (2008) Germinação de espécies arbóreas de floresta estacional decidual do vale do rio Paranã em Goiás após três tipos de armazenamento por até 15 meses. Biota Neotropica 8:89-97

Loik ME, Holl KD (2001) Photosynthetic responses of tree seedlings in grass and under shrubs in early-successional tropical old fields, Costa Rica. Oecologia 127:40-50

McLaren KP, McDonald MA (2003) The effects of moisture and shade on seed germination and seedling survival in a tropical dry forest in Jamaica. For Ecol Manag 183:61-75

Negreros-Castillo P, Snook LK, Mize CW (2003) Regenerating mahogany (Swietenia macrophylla) from seed in Quintana Roo, Mexico: the effects of sowing method and clearing treatment. For Ecol Manag 183:351-362

Nepstad DC, Uhl C, Pereira CA, da Silva JMC (1996) A comparative study of tree establishment in abandoned pasture and mature forest of eastern Amazonia. Oikos 76:25-39

Osunkoya OO, Ash JE, Hopkins MS, Graham AW (1994) Influence of seed size and seedling ecological attributes on shadetolerance of rain-forest tree species in northern Queensland. J Ecol 82:149-163

Parrotta JA, Knowles OH (1999) Restoration of tropical moist forest on degraded bauxite mined lands in the Brazilian Amazon. Restor Ecol 7:103-116

Paz H, Susan JM, Martínez-Ramos M (1999) Seed mass, seedling emergence, and environmental factors in seven rain forest Psychotria (Rubiaceae). Ecology 80:1594-1606

Peña-Claros M, De Boo H (2002) The effect of forest successional stage on seed removal of tropical rain forest tree species. J Trop Ecol 18:261-274

Pereira SR, Laura VA, Souza ALT (2013) Establishment of Fabaceae tree species in a tropical pasture: influence of seed size and weeding methods. Restor Ecol 21:67-74

Ray GJ, Brown BJ (1995) Restoring Caribbean dry forests: evaluation of tree propagation techniques. Restor Ecol 3:86-94

Sampaio AB, Holl KD, Scariot A (2007a) Does restoration enhance regeneration of seasonal deciduous forests in pastures in Central Brazil? Restor Ecol 15:462-471

Sampaio AB, Holl KD, Scariot A (2007b) Regeneration of seasonal deciduous forest tree species in long-used pastures in Central Brazil. Biotropica 39:655-659

SAS Institute Inc. (1994) SAS technical report P-243, SAS/STAT software: the GENMOD procedure, release 6.09. SAS Institute Inc., Cary
SAS Institute Inc. (1999) SAS/STAT user's guide, version 8. SAS Institute Inc., Cary

Scariot A, Sevilha AC (2005) Biodiversidade, estrutura e conservação das florestas estacionais deciduais no cerrado. In: Scariot A, Sousa-Silva JC, Felfili J (eds) Cerrado: Ecologia, Biodiversidade e Conservação. Ministério do Meio Ambiente, Brasília, pp 121-139

Schupp EW (1988) Seed and early seedling predation in the forest understory and in treefall gaps. Oikos 51:71-78

Shankar U (2006) Seed size as a predictor of germination success and early seedling growth in 'hollong' (Dipterocarpus macrocarpus Vesque). New Forest 31:305-320

Sovu PS, Tigabu M, Odén PC (2010) Restoration of former grazing lands in the highlands of Laos using direct seeding of four native tree species: seedling establishment and growth performance. Mt Res Dev 30:232-243

Stokes ME, Davis CS, Koch GG (1995) Categorical data analysis using the SAS system. SAS Institute Inc., Cary

Tunjai P, Elliot S (2012) Effects of seed traits on the success of direct seeding for restoring southern Thailand's lowland evergreen forest ecosystem. New Forest 43:319-333

Uhl C, Buschbacher R, Serrão EAS (1988) Abandoned pasture in eastern Amazonia: 1. Patterns of plant succession. J Ecol 76:663-681

Vieira DLM, Scariot A (2006a) Principles of natural regeneration of tropical dry forests for restoration. Restor Ecol 14:11-20

Vieira DLM, Scariot A (2006b) Effects of logging, liana tangles and pasture on seed fate of dry forest tree species in Central Brazil. For Ecol Manag 230:197-205

Vieira DLM, Lima VVD, Sevilha AC, Scariot A (2008) Consequences of dry-season seed dispersal on seedling establishment of dry forest trees: should we store seeds until the rains? For Ecol Manag 256:471-481

Wang JH, Baskin CC, Cui XL, Du GZ (2009) Effect of phylogeny, life history and habitat correlates on seed germination of 69 arid and semi-arid zone species from northwest China. Evol Ecol 23:827-846

Wang JH, Chen W, Baskin CC, Baskin J, Cui XL, Zhang Y, Qiang WY, Du GZ (2012) Variation in seed germination of 86 subalpine forest species from the eastern Tibetan Plateau: phylogeny and life-history correlates. Ecol Res 27:453-465

Yang W, Liu F, Zhang S, An S (2013) Dispersal and germination syndromes of tree seeds in a seasonal evergreen monsoon rainforest on Hainan Island, China. Seed Sci Res 23:41-55

Zar JH (1999) Biostatistical analysis. Prentice Hall Inc., New Jersey

Zimmerman JK, Pascarella JB, Aide TM (2000) Barriers to forest regeneration in an abandoned pasture in Puerto Rico. Restor Ecol 8:350-360 